\title{
EVALUATION OF SLOW RELEASE FERTILIZER ON THE INITIAL DEVELOPMENT AND COFFEE PRODUCTION
}

\author{
Kleso Silva Franco Junior ${ }^{1}$, Julian Silva Carvalho², Bernardino Cangussu Guimarães ${ }^{3}$, \\ Camila Karen Reis Barbosa ${ }^{4}$, Giselle Prado Brigante ${ }^{5}$, Marcio de Souza Dias ${ }^{6}$, \\ André Aprelini ${ }^{7}$, Nilton de Oliveira Silva ${ }^{8}$
}

(Received: October 21, 2019; accepted: November 25, 2019)

\begin{abstract}
The objective in this work was to evaluate the efficiency of slow release fertilizer in seedling production, initial development and first coffee production. The research was carried out at Sitio Santa Felicidade, Campestre - MG, Brazil, in a randomized block design with two treatments and ten replicates, totaling 20 experimental plots. Coffee seedlings were produced using Ciclus Substrate $\left(20 \% \mathrm{~N}, 22 \% \mathrm{P}_{2} \mathrm{O}_{5}\right.$ and $\left.5 \% \mathrm{~K}_{2} \mathrm{O}\right)$ and conventional fertilizers $4 \mathrm{~kg}$ simple super phosphate $\left(18 \% \mathrm{P}_{2} \mathrm{O}_{5}\right)$ and $0.25 \mathrm{~kg}$ Potassium Chloride $\left(58 \% \mathrm{~K}_{2} \mathrm{O}\right)$. The variables evaluated were size, dry and fresh matter of the shoot and root system, and the seedlings were transplanted to the field and those from Ciclus Substrate received in the first year Ciclus NS $(30 \% \mathrm{~N})$ and in the second year. NK (19-00-19) and conventionally produced with conventional fertilizers (20-00-20 and 25-00-25 respectively), the variables evaluated were: shoot growth, length and number of plagiotropic branch internodes Slow release fertilizer ciclus Substrate has been found to be a viable technology for the production of arabica coffee seedlings, coffee planting NS provides good plant development and coffee producing NK provides good plant growth and higher productivity.
\end{abstract}

Index terms: Coffea arabica L., Ciclus, Productivity.

\section{INTRODUCTION}

More sustainable production systems in coffee growing have aroused the interest of researchers, seeking responsible and more efficient mechanisms in plant nutrition. Studies and tools that describe the sustainable development practices of coffee growing, nutrient effectiveness in relation to productivity increases with economic return are essential. Nutritional imbalance has a direct impact on crop yields, being one of the major contributors to production declines (Silva \& Lima, 2012).

Brazilian soils have the characteristic of high acidity and low fertility (Franco Junior, 2017), being dependent on high doses of fertilizers, directly impacting the final value of the harvested product, making a good soil sampling to be the basis for Proper planning of the use of correctives and fertilizers and, combined with proper management practices, enable high productivity to be achieved (Guarçoni et al., 2017). However, due to the high cost of fertilizers and the low natural fertility in Brazilian soils, the development of techniques to increase the effectiveness of the fertilizers to be used is increasingly urgent.

Due to the agricultural areas advancement, especially in the cerrado and the need for productivity gains, the fertilizers availability in the market has become a concern for the production system, since $70 \%$ these fertilizers are imported (Brandão; Penedo; Bastian Pinto, 2013). This scenario also applies to coffee growing, which has expanded into the cerrado, Western Bahia, Northern Minas Gerais. It is worth mentioning that in traditional coffee growing regions, two actions have marked the activity, the opening of new cultivation areas, when possible, and the renewal coffee crops.

Thus, sustainable practices that improve fertility, such as replacing mineral nitrogen with other practices, without affecting productivity and production cost should be adopted.

Fertilizers and correctives are estimated to account for $30 \%$ of the coffee production cost, and in Brazil nitrogenous fertilizers consume approximately 3.5 million tons annually (Rodrigues et al., 2015). Thus sustainable practices that improve fertility, such as replacing mineral nitrogen with other practices, without affecting productivity and production cost should be adopted. Productivity of perennial species has its growth rate affected by nutritional restrictions, high acidity, and an adequate nutritional diagnosis "soil sampling" is essential for successful implantation (Natale et al., 2012). The nutritional demand of plants is directly related to the contents of the plant material and the total dry matter produced (Castoldi et al., 2009).

\footnotetext{
${ }^{1,4,5,7}$ Centro Superior de Ensino e Pesquisa de Machado - CESEP - Av. Dr. Athaide Pereira de Souza s/n 37.750 - 000 Machado - MG kleso.junior@yahoo.com.br, camilakarenr@gmail.com, giselle.brigante@gmail.com, ap.aprelini@gmail.com

${ }^{6}$ Secretaria de Estado de Educação de Minas Gerais - Escola Estadual Diretor Nelson Rodrigues n. 681 - 37.136-000 - Serrania - MG marciodesouzadias2013@gmail.com

2,3,8 Empresa de Assistência Técnica E Extensão Rural de Minas Gerais - EMATER MG- Av. Raja Gabaglia, 1626 - B. Gutierrez 30.441-194 - Belo Horizonte - MG - bernardino@emater.mg.gov.br, julian@emater.mg.gov.br, nilton.silva@emater.mg.gov.br
} 
Plant nutritional imbalance promotes abnormalities, characteristics of each nutrient in deficiency or excess. The symptomatology results from the fact that each element exerts in the metabolic function, whatever the plant, being able to express in leaves, stems and roots, thus indicating the nutritional state of the vegetable.

The traditional coffee seedling production and marketing system is composed of polyethylene bags with substrates (Nasser et al., 2009). Generally these substrates are composed of soil, organic material (manure or organic compost) and mineral fertilizers. The new technology in seedling production is the use of slow release and controlled fertilizers, which are soluble and grouped in granules coated with organic or even elastic resin. In order to minimize problems with burning the roots by over fertilization and promote slow release, which is of utmost importance. Thus the nutrient release is continuous and according to the temperature and humidity of the soil (Simão, 2017).

Slow release fertilizers in their various forms are very useful for producing seedlings in containers. The main idea of slow release fertilizers is the continuous release of nutrients, keeping the plant continuously nourished in its growing period. The advantages of using it are numerous, among them the reduction of labor and less nitrogen loss through volatilization (Sharma, 1979; Simão, 2017).

Nutrients in slow release fertilizers include soluble compounds inside them (NPK and some micronutrients), surrounded by a semipermeable membrane which, due to temperature, has an elastic characteristic and, therefore, the ability to dilate and contract, controlling the gradual release and osmotic nutrients to the substrate (Santos et al., 2018), maintaining constant levels of the essential elements for seedlings throughout the growing period (Jose; Davide; Oliveira, 2005; Rossa et al., 2015).

To obtain quality seedlings, the morphological parameters must be observed. According to Dardengo et al. 2013, the main parameters that determine seedling quality are height, neck diameter, shoot and root weight, and the correlation between these parameters with the height and neck diameter ratio.

Coffee, just like any species, needs various nutrients for its complete development. Coffee growers already have technical bulletins with recommendations for coffee nutrition at all stages of their cycle (planting, first and second year of formation and crops in production (Vilela et al., 2017).

Growth can be defined as net accumulation of carbon and other organic components in plants, and carbon gain is determined by local availability of light, water and nutrients (Buchanan; Gruissen; Jones, 2000). In practice, for measuring growth, the dry matter produced over a period of time can be evaluated by the absolute growth rate and the relative growth rate. The first index represents the dry matter produced per unit area or plant over a period of time and the second index represents the dynamics of dry matter accumulation over time, related to its initial dry matter (Hunt et al., 2002). Thus, the relative growth rate represents the accumulation of dry matter per unit of dry matter and per unit of time.

Genetic and edaphoclimatic factors directly influence coffee growth. Research has been conducted and evidenced that Coffea arabica has its own species-specific characteristics (Fonseca, et al., 2006).

The objective in this work was to evaluate the efficiency of slow release fertilizer in seedling production, initial development and first coffee production.

\section{MATERIAL AND METHODS}

The experiment was carried out from May 2016 to May 2019 at Sitio Santa Felicidade, Campestre - Southern MG, located at the geographic coordinates: $21^{\circ} 43^{\prime} 12^{\prime \prime}$ South and $46^{\circ} 14^{\prime} 45^{\prime}$ "West, at an altitude of 1.112 meters and with hot and temperate climate. The summer with higher rainfall than winter is classified as Cwb according to Köppen (1936) and Geiger (1954). The average annual temperature is $18.9^{\circ} \mathrm{C}$ and the average rainfall is $1609 \mathrm{~mm}$ according to the Clima-Date.Org website.

The research was carried out in two stages, the first, the evaluation of seedlings and the second, evaluation of the development and production of adult plants.

The experiment was carried out in a randomized block design (DBC) with two treatments (slow release and conventional fertilizer) and ten replicates, totaling twenty experimental units. Each plot consisted of 50 seedlings.

The Arabica coffee (Coffeea arabica) cultivar used was Topaz. For the production of the seedlings $11 \times 22 \mathrm{~cm}$ bags were used, containing 
subtract composed of soil and tanned manure, in the proportions of 3:1 and the treatment using was $1.4 \mathrm{~kg}$ of Ciclus Substrate $\left(20 \% \mathrm{~N}, 22 \% \mathrm{P}_{2} \mathrm{O}_{5}\right.$ and $5 \% \mathrm{~K}_{2} \mathrm{O}$ ) and conventional fertilizers with $2.0 \mathrm{~kg}$ simple super phosphate $\left(18 \% \mathrm{P}_{2} \mathrm{O}_{5}\right)$ and $0.25 \mathrm{~kg}$ potassium chloride $\left(58 \% \mathrm{~K}_{2} \mathrm{O}\right)$.

When the seedlings had 4 definite pairs of leaves, the following parameters were evaluated: shoot height, root system length, fresh and dry weight of shoot and root system. Height and length evaluations were performed with the aid of a graduated ruler. The seedlings were dried in a greenhouse with forced air circulation at $65{ }^{\circ} \mathrm{C}$, using six seedlings for each plot.

Secondly, after the seedling evaluation, twenty remaining seedlings of each plot were transplanted in the field (definitive planting), with a spacing of $3.5 \times 0.5 \mathrm{~m}$. The seedlings that were produced with Ciclus Substrate used the treatment with ciclus NS at a dosage of $20 \mathrm{~g}$ per pit and the seedlings that were conventionally produced received four $10 \mathrm{~g}$ of $20-00-20$ per pit, in addition to eight liters of tanned manure per plant in all treatments.

After the first year of planting, the six central plants of each plot were evaluated: shoot growth at plant height, plagiotropic branch length and number of plagiotropic internodes evaluated.

In the second year, $100 \mathrm{~g}$ of Cyclus NK (1900-19) was applied to plants from ciclus Substrate seedlings and to the conventional three fertilizers with $50 \mathrm{~g}$ of $25-00-25$ per plant.

In the same six central plants, plant growth in height, plagiotropic branch length at $50 \mathrm{~cm}$ from ground level, number of internodes and yield were evaluated.

For the first production, the same six central plants were evaluated and the measurement performed in liters per plant and converted by productivity, considering 500 liters.bag ${ }^{-1}$.

Data were statistically interpreted by analysis of variance. The means were grouped by Scott-Knott test at 5\% probability, using the statistical software SISVAR ${ }^{\circledR}$ (Ferreira, 2014).

\section{RESULTS AND DISCUSSION}

In evaluating coffee seedlings development, it was possible to observe that, for the shoot height there was no statistical difference between the treatments used (Table 1). Regarding the root system length, the slow release fertilizer Ciclus Substrate was more efficient, providing higher growth when compared to the conventional one (Table 1). Similar effect was observed when evaluating the seedlings total length, in which the use of slow release fertilizer also promoted better development, confirming the study by Bachião et al. (2018).

Oliveira et al. (2018) and Santos et al. (2018), in their research, also obtained results in which the seedlings production using slow release fertilizers resulted in better root system development.

The variance analysis showed statistical difference between treatments regarding fresh matter of coffee seedlings. It turns out that, greatest fresh matter was produced by the root system when using the Ciclus Substrate (Table 2). This result influences in the total fresh matter, with a difference $0.54 \mathrm{~g}$ in relation to the conventional one.

Regarding the seedlings dry weight, there was no statistical difference between treatments (Table 3), contrary to data from Oliveira et al. (2018), in which the dry matter of the root system of coffee seedlings produced with Ciclus was higher than that produced using conventional fertilizers.

According to Sgarbi et al. (1999) and França et al. (2009) the application of Osmocote ${ }^{\circledR}$ (19-0610) to the Eucalyptus urophylla clone provided higher growth and higher dry weight root using slow release fertilizers to the substrate compared to conventional fertilization.

Analyzing the results obtained after the first year of transplantation (Table 4), it was possible to observe that the plants which came from the seedlings produced with slow release fertilizers and received application of the same technology, presented a higher height, differing statistically from the plants of conventional fertilizers. However, when analyzing plagiotropic branch length and number of internodes, no statistical differences were observed (Table 4).

After the second year of transplantation, the average tests show that plants from controlled release fertilizer seedlings managed in the first and second year resulted in higher plants with longer plagiotropic branch length and higher number of internodes (Table 5). Pinto et al. (2011), reports that Ciclus promoted increase in plagiotropic branch length and number of internodes compared to conventional fertilizer.

The first coffee production demonstrated superior productivity in Ciclus managed plants, resulting in a differential 3.2 more coffee bags when compared to the conventional one (Table 6). Pinto et al. (2011) and Pinto, Barbosa e Santana (2012), report that Ciclus promoted productivity increase in coffee crop. 
TABLE 1- Coffee seedlings development (cm).

\begin{tabular}{cccc}
\hline Treatments & Shoot height & Root system length & Total length \\
\hline Ciclus Substrate & $23.7 \mathrm{~A}$ & $20.4 \mathrm{~A}$ & $44.10 \mathrm{~A}$ \\
\hline Conventional & $21.9 \mathrm{~A}$ & $18.7 \mathrm{~B}$ & $40.60 \mathrm{~B}$ \\
\hline *Averages followed by the same letter belong to the same cluster by the Scott-Knott test at 5\% probability.
\end{tabular}

TABLE 2- Fresh matter (grams) of coffee seedlings.

\begin{tabular}{cccc}
\hline Treatments & Shoot fresh matter & Root fresh matter & Total fresh matter \\
\hline Ciclus Substrate & $7.44 \mathrm{~A}$ & $3.82 \mathrm{~A}$ & $11.26 \mathrm{~A}$ \\
Conventional & $7.17 \mathrm{~A}$ & $3.55 \mathrm{~B}$ & $10.72 \mathrm{~B}$ \\
\hline *Averages followed by the same letter belong to the same cluster by the Scott-Knott test at 5\% probability.
\end{tabular}

${ }^{*}$ Averages followed by the same letter belong to the same cluster by the Scott-Knott test at $5 \%$ probability.

TABLE 3 - Dry weight (grams) of coffee seedlings

\begin{tabular}{cccc}
\hline Treatments & Dry weight shoot & Dry weight root & Total dry weight \\
\hline Ciclus Substrate & $1.83 \mathrm{~A}$ & $0.55 \mathrm{~A}$ & $2.38 \mathrm{~A}$ \\
Conventional & $1.78 \mathrm{~A}$ & $0.48 \mathrm{~A}$ & $2.26 \mathrm{~A}$ \\
\hline
\end{tabular}

*Averages followed by the same letter belong to the same cluster by the Scott-Knott test at $5 \%$ probability.

TABLE 4 - Plant height, length and number of internodes in plagiotropic branches in the first year.

\begin{tabular}{cccc}
\hline Treatments & $\begin{array}{c}\text { Height } \\
(\mathrm{cm})\end{array}$ & $\begin{array}{c}\text { Plagiotropic length } \\
(\mathrm{cm})\end{array}$ & $\begin{array}{c}\text { Number of internodes in } \\
\text { plagiotropic }\end{array}$ \\
\hline Ciclus NS & $62.2 \mathrm{~A}$ & $48.4 \mathrm{~A}$ & $8.2 \mathrm{~A}$ \\
Conventional & $55.7 \mathrm{~B}$ & $42.5 \mathrm{~A}$ & $7.9 \mathrm{~A}$ \\
\hline * Averages followed by the same letter belong to the same cluster by the Scott-Knott test at 5\% probability.
\end{tabular}

*Averages followed by the same letter belong to the same cluster by the Scott-Knott test at $5 \%$ probability.

TABLE 5 - Plant height, length and number of internodes in the plagiotropic branches in the second year.

\begin{tabular}{cccc}
\hline Treatments & $\begin{array}{c}\text { Height } \\
(\mathrm{cm})\end{array}$ & $\begin{array}{c}\text { Length plagiotropic at } 50 \mathrm{~cm} \text { from } \\
\text { the ground } \\
(\mathrm{cm})\end{array}$ & $\begin{array}{c}\text { Number of internodes in } \\
\text { plagiotropic }\end{array}$ \\
\hline Ciclus NK & $119 \mathrm{~A}$ & $76.3 \mathrm{~A}$ & $17.8 \mathrm{~A}$ \\
Conventional & $105 \mathrm{~B}$ & $69.2 \mathrm{~B}$ & $15.2 \mathrm{~B}$ \\
\hline *Averages followed by the same letter belong to the same cluster by the Scott-Knott test at 5\% probability.
\end{tabular}

TABLE 6 - Productivity at first crop (bags ha $\left.{ }^{-1}\right)$

\begin{tabular}{cc}
\hline Treatments & Productivity \\
\hline Ciclus & $28.32 \mathrm{~A}$ \\
Conventional & $25.08 \mathrm{~B}$ \\
\hline
\end{tabular}

*Averages followed by the same letter belong to the same cluster by the Scott-Knott test at 5\% probability. 


\section{CONCLUSIONS}

It is concluded that, slow release fertilizer Ciclus Substrate has been found to be a viable technology for the production of quality arabica coffee seedlings, Ciclus NS for coffee planting provides good plant development and NK as fertilizer for coffee producing provides good plant growth and higher productivity.

\section{ACKNOWLEDGMENTS}

The authors are grateful to Higher Education and Research Center (CESEP), CESEP's Coffee Research Center at Minas Gerais State, Technical Assistance and Extension Company - EMATER - MG, to the owner of Sítio Santa Felicidade, and Higher Education Personnel Improvement Coordination - CAPES, that contributed much to the development of this research.

\section{REFERENCES}

BACHIÃO, P.O.B; MACIEL, A.L.R, AVILA, R.G CAMPOS, C.N. Crescimento de mudas de cafeeiro em tubetes com fertilizante de liberação lenta, Revista Agrogeoambiental, Pouso Alegre, v.10, n.1, p.105116, mar. 2018. DOI: http://dx.doi.org/10.18406/2316$1817 \mathrm{v} 10 \mathrm{n} 12$

BUCHANAN, B.B.; GRUISSEN, W.; JONES, R.L. (eds.). 2000. Biochemistry and molecular biology of plants. American Society of Plant Physiologists, Rockville

BRANDÃO, L.E.T; PENEDO, G.M.; BASTIANPINTO, C. The value of switching inputs in a biodiesel production plant. The European Journal of Finance, vol. 19(7-8), pages 674-688, September. 2013.

CASTOLDI, R.; CHARLO, H.C.O.; VARGAS, P.F.; BRAZ, L.T. Crescimento, acúmulo de nutrientes e produtividade da cultura da couve-flor. Horticultura Brasileira, v.27, n.1, p. 438-446. 2009.

DARDENGO, M.L.J.D; SOUZA E.F.; REIS, E.F.; GRAVINA, G.A. Crescimento e qualidade de mudas de café conilon produzidas em diferentes níveis de sombreamento, Coffee Science, Lavras, v. 8, n. 4, p. 500-509 out./dez. 2013.

FERREIRA, D.F. Sisvar: um guia dos seus procedimentos de comparações múltiplas Bootstrap. A Ciência e agrotecnologia. [online]. v..38, n.2, pp.109112. 2014.
FONSECA, A.F.A.; SEDIYAMA, T.; CRUZ, C.D.; SAKAIYAMA, N.S.; FERRÃO, M.A.G.; FERRÃO, R.G.; BRAGANÇA, S.M. Divergência genética em café Conilon. Pesquisa Agropecuária Brasileira, v. 41, n. 6, p. 599-605, 2006

FRANÇA, L.V.; DUBOC, E.; JUNQUEIRA, N.T.V. Efeito de diferentes doses de fertilizante de liberação controlada em mudas de pequi (Caryocar brasiliense Camb.). EMBRAPA (Separatas): v.1, p.1-7. 2009.

FRANCO JUNIOR, K. S. Uso de bioativador de solo associado a diferentes coberturas vegetais e a influência nas características químicas, físicas e microbiológicas. 2017. 82 f. Dissertação (Programa de Mestrado em Sistemas de Produção na Agropecuária) - Universidade José do Rosário Vellano, Alfenas.

GEIGER, R. KASSIFIKATION DER KLIMATE NACH. INLANDOLTBÖRNSTEIN ZAHLENWERTE UND FUNKTIONEN AUS PHYSIK, CHEMIE, ASTRONOMIE, GEOPHYSIK UND TECHNIK, VOL. 3, KÖPPEN W (ED). Springer: Berlin, 603-607. 1954.

GUARÇONI, A.; ALVAREZ, V.; VÍCTOR HUGO; SOBREIRA, F. M. Fundamentação teórica dos sistemas de amostragem de solo de acordo com a variabilidade de características químicas. Terra Latinoam, Chapingo, v. 35, n. 4, p. 343-352, Dic. 2017.

HUNT, R.; CAUSTON, D.R.; SHIPLEY, B.; ASKEW, P. A modern tool for classical plant growth analysis. Annals of Botany, v.90, p.485-488. 2002.

JOSE, A.C.; DAVIDE, A.C.; OLIVEIRA, S.L. Produção de mudas de aroeira (Schinus terebinthifolia Raddi) para recuperação de áreas degradadas pela mineração de bauxita. Cerne, vol.11, n.2, p.187-203, 2005.

KÖPPEN, W.P. DAS GEOGRAPHISCHE SYSTEM DER KLIMATE. Gebrüder Borntraeger: Berlin. 1936.

NASSER, M.D.; LIMA JUNIOR, S.; GALLO, P.B.; SOUZA, P.S.; BREDAJÚNIOR, J.M. Desenvolvimento e qualidade de midas de café (Coffea arábica L.) produzidas em sacola plástica convencional, tubete e sacola de tnt. In: Simpósio de Pesquisa dos Cafés do Brasil (6.: 2009: Vitória, ES). Anais Brasília, DF: EMBRAPA - Café, 2011. 
NATALE, W.; ROZANE, D.E.; PARENT, L.E.; PARENT, S.E. Acidez do solo e calagem em pomares de frutíferas torpicais. Revista Brasileira de Furticultura, v.34, n.4, p. 1294-1306, Dezembro. 2012.

OLIVEIRA, P.C.; FRANCO JUNIOR, K.S.; BRIGANTE, G.P.; SILVA, T.M. Efeito do adubo de liberação lenta no crescimento e desenvolvimento do sistema radicular de mudas de café arábica. Revista Cerrado Agrociências, n.9, p. 105 - 110, nov. 2018.

PINTO, M.F.; REZENDE, M.C.; SANTANA, M.R.; GOMES, M.T.B.; LEITE, J.F.A. Resultados Parciais do produto ciclus NK, nitrogenio de liberação lenta, aplicados a lavoura em produção. 37. ${ }^{\circ}$ Congresso Brasileiro de Pesquisas Cafeeiras, Araxá MG, 2011. Disponível em http://www.sapc.embrapa.br/arquivos/ consorcio/spcb_anais/simposio7/42.pdf

PINTO, M.F.; BARBOSA, C.M.; SANTANA, M.R. Comportamento do adubo de liberação lenta Ciclus NK, uma única aplicação, na cafeicultura da Zona da Mata, $38^{\circ}$ Congresso Brasileiro de Pesquisas Cafeeiras, Caxambu MG, 2012.

RODRIGUES, R.B.; OZORIO, L.M.; PINTO, C.L.B; BRANDÃO, L.E.T. Opção de troca de produto na indústria de fertilizantes. Revista Administração., São Paulo, v.50, n.2, p.129-140, abr./maio/jun. 2015

ROSSA, U.B.; ANGELO, A.C.; WESTPHALEN, D.J.; OLIVEIRA, F.E.M.; SILVA, F.F.; ARAUJO, J.C. Fertilizante de liberação lenta no desenvolvimento de mudas de Anadenanthera peregrina (L.) Speg. (ANGICO-VERMELHO) E Schinus terebinthifolius Raddi (AROEIRA-VERMELHA). Ciência Florestal, 25(4), 841-852. 2015
SGARBI, F.; SILVEIORA, R.V.A.; HIGASHI, E.N.; PAULA, T.A.; MOREIRA, A.; RIBEIRO, F.A. Influência de aplicação de fertilizantes de liberação controlada na produção de mudas de um clone de Eucalyptus urophylla. 2. ed. Piracicaba: IPEFESALQ, 1999.

SANTOS, P.L.F.; PAIXÃO, A.P.; SILVA, O.N.M.; CASTILHO, R.M.M.; FARIA, R.C.; VIEIRA, N.C.S. Doses de adubo de liberação lenta no crescimento inicial de mudas de tamarindo. Nucleus, v. 15, n.1, p. 137-146, abr. 2018.

SERRANO, L.A.L.; SILVA, C.M.M; OGLIARU, J; CARVALHO, A. J.C.; MARINHO, C. S.; DETMANN, E. Utilização de substrato composto por resíduos da agroindústria canavieira para produção de mudas de maracujazeiro-amarelo. Revista Brasileira de Fruticultura, Jaboticabal, v.28, n.3, p.487-491, 2006.

SHARMA, G. C. Controlled-release fertilizers and horticultural applications. ScientiaHorticulturae, Alabama, USA, v.11(2): 107-129. 1979.

SILVA, S.A.; LIMA, J.S.S. Avaliação da variabilidade do estado nutricional e produtividade de café por meio da análise de componentes principais e geoestatística. Revista Ceres, Viçosa, v.59, n.2, p. 271-277, Mar./ Apr. 2012.

SIMÃO, L.A. Fertilizante de liberação controlada no crescimento e desenvolvimento de plantas de mamoeiro a campo. Dissertação (Mestrado em Agricultura Tropical). Universidade Federal do Espírito Santo. São Mateus, ES: UFES, 42f. 2017.

VILELA, D.J.M.; CARVALHO, G.R.; BOTELHO, C.E.; CARVALHO, A.M.; PRAXEDES, M.A.; SANTOS, M.C.; FERNANDES, F.C. Crescimento inicial de cultivares de cafeeiro com diferentes doses de nitrogênio, fósforo e potássio. Coffee Science, Lavras, v. 12, n. 4, p. 552 - 561, out./dez. 2017. 